\title{
Peningkatan Efektivitas Pengelolaan Sampah Organik Rumah Tangga Pada Kelompok Dasawisma Jati A dan B di Kota Bengkulu
}

\author{
Ariefa Primair Yani ${ }^{1}$, Deni Parlindungan ${ }^{2 *}$, Bhakti Karyadi ${ }^{3}$ Ika Saputri ${ }^{4}$,Reti \\ Novianti ${ }^{5}$, Widia Gusti ${ }^{6}$ \\ ${ }^{12345}$ Pendidikan IPA,FKIP, Universitas Bengkulu \\ *Corresponding author: dparlindungan@unib.ac.id
}

\begin{tabular}{ll}
\hline Article History: & Abstrak \\
Received: Oktober & Potensi sampah organik rumah tangga yang ada di kelompok \\
2021 & Dasawisma Jati A dan B belum dimanfaatkan dengan baik. \\
Revised: & Pengabdian pada masyarakat berbasis IPTEKS ini bertujuan \\
November 2021 & untuk menginformasikan, memberikan keterampilan, \\
Accepted: & membimbing dan meningkatkan minat masyarakat akan \\
November 2021 & penting produk ekoenzim. Kegiatan pelatihan dilakukan \\
Available online: & melalui tiga langkah berikut, yakni: 1) Eksplorasi: menggali \\
Desember 2021 & pemahaman ekoenzim dan potensi sampah. 2) Pelatihan: \\
& penyampaian materi dan praktek pembuatan ekoenzim \\
& dilakukan langsung oleh peserta dengan bekerja dalam \\
Keywords: & kelompok dan 3) Evaluasi pemantauan kinerja, proses, \\
Bengkulu, & Instrumen dan minat peserta pada pembuatan ekoenzim. \\
Ekoenzim, Organik, & Kegiatan dilaksanakan pada tanggal 10 Oktober 2021. Hasil \\
Sampah & kegiatan menunjukan; banyak sampah organik rumah tangga \\
& yang masih memiliki potensi, meningkatnya upaya masyarakat \\
& dalam pemanfaatan sampah organik, meningkatnya \\
& pemahaman dan muncul minat peserta untuk membuat \\
& ekoenzim sendiri guna memanfaatkan sampah organik di \\
& rumah. Kesimpulan yang diperoleh adalah penerapan IPTEKS \\
& melalui pelatihan pembuatan ekoenzim dapat meningkatkan \\
pengetahuan, keterampilan dan minat pada kelompok & dasawisma Jati A dan B Kota Bengkulu dalam pengelolaan \\
& sampah organik dilingkungan rumah tangga.
\end{tabular}




\section{Pendahuluan}

Sampah organik setiap keluarga di kelompok Dasawisma Jati A dan B sekitar 0,5 - $1 \mathrm{Kg}$ per hari. Sampah organik ini belum maksimal dimanfaatkan dan bahkan sebagaian masih dibuang. Sampah yang dibuang ke lingkungan menjadi masalah buruk, padahal sampah tersebut cenderung masih memiliki potensi untuk dimanfaatkan. Sampah organik biasa digunakan masyarakat untuk bahan baku kompos, sedangkan sampah non organik masih bisa didaur ulang, dijual atau digunakan kembali untuk kegunaan lain. Penanganan sampah melalui 3R (Reduce, Reuse dan Recycle) cenderung sudah diterapkan diberbagai wilayah di Indonesia namun masih juga masalah sampah belum terselesaikan (Nursalim et al., 2020). Sampah dapat menjadi masalah jika tidak dikelola, sebaliknya dapat bermanfaat dan bernilai ekonomis jika mengerti cara mengelolanya. Teknik pengelolaan sampah yang efektif selalu dikembangkan dan bahkan diarahkan untuk mendukung penguatan ekonomi masyarakat (Marleni et al., 2012). Pengelolaan sampah organik bahkan sudah mencapai 5R (Refuse, Reduse, Reuse, Recycle, Rot), dimana pemanfaatan dalam proses Rot (pembusukan) menghasilkan produk bermanfaat yaitu ekoenzim (Zulfikar et al., 2021).

Ekoenzim merupakan cairan berwarna coklat yang dihasilkan dari fermentasi sisa sayuran atau buah-buahan oleh mikroba yang diperkaya dengan substrat gula (Nazim et al., 2015). Cairan yang dihasilkan merupakan cairan multiguna yang dikenalkan oleh Dr. Rosukon Poompanvong (Thailand) dan sudah ditelitinya sekitar 35 tahun lalu. Aplikasinya meliputi penggunaan area rumah tangga (Junaidi et al., 2021), pertanian dan juga peternakan (Ginting et al., 2021). Pada prosesnya untuk menghasilkan enzim yang berguna menggunakan sampah buah atau sayuran yang dibantu gula untuk mempercepat proses biokimia dalam penguraiannya. Cairan dimanfaatkan untuk pembersih rumah, atau sebagai pupuk alami dan pestisida alami yang efektif.

Masyarakat masih membuang sampah organik dan anorganik dengan tanpa memilah dan tidak menilai manfaat dari limbah tersebut. Pemanfaatan 
limbah rumah tangga masih belum dilakukan dengan baik penanganannya dan tidak dijadikan alternatif apapun. Sampah organik dilepas ke tempat akhir dan dibiarkan membusuk padahal masih ada produk yang bisa dibuat dengan sampah tersebut. Perlu solusi mengubah sampah organik menjadi eco-enzyme penting untuk mengurangi jumlah sampah organik yang menumpuk di tempat pembuangan akhir. Ekoenzim yang merupakan produk mudah dibuat dan murah, namun belum dilakukan masyarakat salah satunya di kelompok Dasawisma Jati A dan Jati B Kota Bengkulu. Hal tersebut karena masyarakat belum tahu cara pembuatannya. Untuk itu, penyuluhan tentang pembuatan ekoenzim dan penerapannya penting untuk segera dilakukan pada masyarakat, supaya masyarakat memperoleh pengetahuan dan keterampilan tentang ekoenzim dan diharapkan muncul solusi untuk membantu perbaikan lingkungan kedepannya.

\section{Metode}

Sasaran pengabdian berbasis IPTEK ini adalah kelompok Dasawisma Jati A dan B, yang beranggotakan ibu-ibu. Lokasi pengabdian di Perumas Unib Blok 6, Bentiring Permai,Muara Bangkahulu, Kota Bengkulu. Kegitan dilakukan pada tanggal 10 Oktober 2021, di SBIH Ruyani yakni tempat yang memiliki fasilitas ruang kelas yang mampu menampung cukup banyak peserta dan sudah established untuk kegiatan riset dan pembelajaran untuk masyarakat Bengkulu (Ruyani et al., 2018). Pelaksanaan kegiatan menerapkan protokol kesehatan Covid-19.

Kegiatan pengabdian dilakukan dalam 3 tahapan antara lain;

a) Eksplorasi pemahaman terkait potensi sampah organik sekitar rumah tangga, upaya pemanfaatan yang sudah dilakukan dan pemahaman ekoenzim melalui pertanyaan angket terbuka.

b) Pemberian materi pelatihan disampaikan dengan metode ceramah, diskusi serta demonstrasi dan selanjutnya praktek pembuatan ekoenzim. Praktek pembuatan ekoenzim dilakukan langsung oleh 
peserta dengan bekerja dalam kelompok. Peserta yang berjumlah 11 orang terbagi kedalam 5 kelompok yang beranggotakan 2-3 orang.

c) Evaluasi pemantauan kinerja peserta, proses, pemahaman dan minat peserta, evaluasi dilakukan menggunakan angket.

\section{Hasil dan Pembahasan}

Peserta diminta untuk mengumpulkan terlebih dahulu berbagai jenis sampah organik yang mereka bawa sendiri dari rumah masing-masing lalu memilah dan mengidentifikasinya. Agar kualitas sampah tetap segar maka sampah organik disimpan dalam kulkas. Data menunjukan bahwa sampah organik yang ada merupakan jenis bahan umum berupa kulit buah dan sisa sayuran yang bisa dibuat ekoenzim (Tabel 1), namun bahan yang menjadi sumber ekoenzim harus segar, bebas petisida, bersih, dan bebas minyak. Oleh sebab itu sampah organik yang ada penting untuk dipilah antara sisa buah dan sayuran yang merupakan sampah organik dengan sampah non-organik dan dijaga kesegarannya (Galintin. et.al 2020; Wen. et.al 2021).

Tabel 1. Potensi sampah organik dilingkungan masyarakat Jati A dan B

\begin{tabular}{cll}
\hline No & Sampah Organik & \multicolumn{1}{c}{ Jenis } \\
\hline 1 & Sayuran & $\begin{array}{l}\text { Wortel, timun, bawang merah,bawang putih,kangkung, } \\
\text { sawi, kol,bayam,sirih }\end{array}$ \\
\hline 2 & Buah & $\begin{array}{l}\text { Pisang,papaya,jeruk,melon,nanas,jambu,bengkoang,sem } \\
\text { angka }\end{array}$ \\
\hline
\end{tabular}

Penanganan sampah organik yang sudah mereka lakukan dirumah selama ini adalah sebagai pupuk dan pakan atau langsung dibuang (Tabel 2). Masyarakat sadar akan manfaat sampah organik sebagai pupuk dan pakan lebih sedikit $(45,5 \%)$ dibandingkan yang hanya membuang sampah organik tanpa ada upaya pemanfaatan $(54,4 \%)$. Masyarakat belum menggunakan sampah organik dan cenderung membuang ketempat akhir. Limbah makanan yang rata-rata mencapai $60 \%$ dari total isi TPA dibiarkan membusuk di tempat pembuangan akhir atau di bawah tanah. Kebiaasaan buruk ini tidak hanya 
menjadikan makanan terbuang tetapi semua sumber daya lain menjadi terganggu seperti tanah, air, energi, dan keragaman spesies (Wen et al., 2021). Tabel 2. Upaya pengelolaan sampah organik

\begin{tabular}{llccl}
\hline No & $\begin{array}{l}\text { Indikator Upaya } \\
\text { pemanfaatan sampah }\end{array}$ & $\begin{array}{c}\text { Jumlah } \\
\text { responden }\end{array}$ & $\begin{array}{c}\text { Persentase } \\
(\boldsymbol{\%})\end{array}$ & $\begin{array}{c}\text { Jenis Upaya } \\
\text { pemanfaatan sampah }\end{array}$ \\
\hline 1 & Ada & 5 & 45,5 & Pupuk dan Pakan ternak \\
\hline 2 & Belum ada & 6 & 54,5 & dibuang \\
\hline
\end{tabular}

Pengetahuan akan ekoenzim masyarakat akan ekoenzim diketahui masih rendah. Berdasarkan hasil angket terbuka diperoleh $100 \%$ peserta belum mengenal ekoenzim (Tabel 3). Peserta belum mengenal ekoenzim dan lebih mengenal pupuk organik cair (POC) yang cenderung lebih dulu mereka ketahui sebelumnya. Kebanyakan masyarakat Indonesia belum memahami ekoenzim (Arifin et al., 2009). Ekoenzim yang lebih dulu popular di negara Thailand dan Malaysia, namun di Indonesia justru belum lama ini. Ini menjadi hal penting perlu adanya sosialisasi akan pemanfaatan sampah organik melalui pembuatan ekoenzim salahsatunya. Penting untuk memulai memberikan pemahaman akan pemanfaatan sampah, hal ini guna memberikan langkah kecil yang berkesinambungan untuk menuju lingkungan yang lebih baik. Di negara majupun upaya ini terus dilakukan meskipun dibeberapa masih ada yang belum tertib melakukan upaya baik ini. Umumnya masalah sampah berimplikasi pada kebijakan baik pada pencegahan maupun pengelolaan limbah makanan rumah tangga yang diterapkan pada wilayah tersebut (De Laurentiis et al., 2018).

Tabel 3. Pengetahuan awal peserta akan ekoenzim

\begin{tabular}{llcc}
\hline No & $\begin{array}{l}\text { Indikator pengetahuan } \\
\text { ekoenzim }\end{array}$ & Jumlah responden & Persentase (\%) \\
\hline 1 & Tidak Tahu & 11 & 100 \\
\hline 2 & Tahu & 0 & 0 \\
\hline
\end{tabular}

Minat masyarakat terlihat tinggi (100\%) dalam membuat ekoenzim sendiri (tabel.4). Pengetahuan dan keterampilan baru tentang ekoenzim 
mampu merangsang kesadaran positif peserta untuk melakukannya secara mandiri. Metode yang dianggap mudah dan biaya yang murah memicu minat peserta untuk melakukannya sendiri karena dianggap efisien. Perlu upaya lebih dalam mengubah minat dan kebiasaan masyarakat agar dapat berubah dengan tanpa ada paksaan salahsatunya dengan kegiatan penyuluhan (Gambar.1; Zakianis et al., 2017).
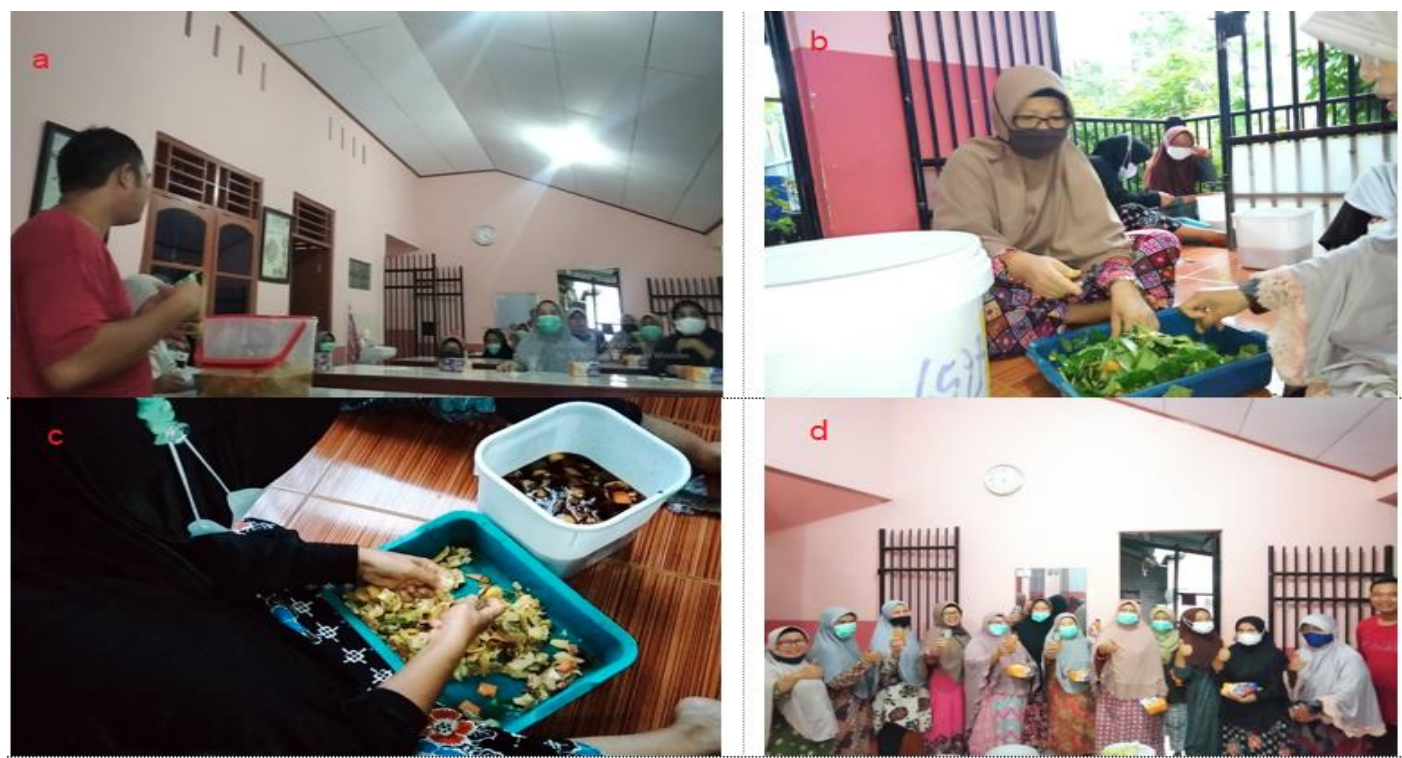

Gambar 1: a) Pemberian materi terkait ekoenzim; b) Pembuatan ekoenzim berbahan sampah sayuran;c) berbahan buah; d) Peserta pelatihan kelompok Dasawisma Jati A dan B perumnas Unib

Tabel 4. Ketertarikan membuat ekoenzim

\begin{tabular}{llcc}
\hline No & $\begin{array}{l}\text { Ketertarikan membuat } \\
\text { ekoenzim }\end{array}$ & Jumlah responden & $\begin{array}{c}\text { Persentase } \\
(\boldsymbol{\%})\end{array}$ \\
\hline 1 & Tertarik & 11 & 100 \\
\hline 2 & Tidak Tertarik & 0 & 0 \\
\hline
\end{tabular}

Ada nilai IPTEK yang bersifat baru yang dirasakan peserta saat mengikuti pelatihan. Materi yang disampaikan menjadi informasi baru yang 
mereka dapatkan dan menjadi pengalaman baru pula dalam membuat ekoenzim. Penggunaan enzim dari sampah organik limbah dapur (sayur dan buah), air dan gula merah, muncul sebagai metode yang efektif untuk dimanfaatkan. Ekoenzim merupakan produk fermentasi yang banyak manfaat namun caranya cukup mudah untuk diterapkan di rumahan. Kegiatan pengabdian yang dilakukan mampu memberikan pengetahuan, keterampilan dan minat yang baik tentang ekoenzim pada masyarakat Jati A dan B. Tercapainya kegiatan pengabdian berupa pelatihan ekoenzim dapat dilihat melalui kegiatan yang sesuai dengan tujuan kegiatan pengabdian masyarakat, partisipasi dan antusias peserta selama kegiatan berlangsung hingga tuntas (Yanti et al., 2021).

\section{Kesimpulan}

Penerapan IPTEKS melalui pelatihan pembuatan ekoenzim dapat meningkatkan pengetahuan, keterampilan dan minat pada kelompok dasawisma Jati A dan B Kota Bengkulu dalam pengelolaan sampah organik di lingkungan rumah tangga.

\section{Ucapan Terima Kasih}

Penulis mengucapkan terima kasih kepada Fakultas Keguruan dan Ilmu Pendidikan Universitas Bengkulu yang telah mendanai kegiatan melalui program Pengabdian Berbasis IPTEKS Tahun 2021, kelompok Dasawisma Jati A dan B Perumnas Unib atas kesediaannya sebagai mitra dan SBIH Ruyani yang sudah memfasilitasi pelaksanaan pengabdian ini.

\section{Daftar pustaka}

Arifin, L. W., Syambarkah, A., Purbasari, H. S., Ria, R., \& Puspita, V. A. (2009). Introduction of eco-enzyme to support organic farming in Indonesia. Asian Journal of Food and Agro-Industry, 2 (Special Issue). 
De Laurentiis, V., Corrado, S., \& Sala, S. (2018). Quantifying household waste of fresh fruit and vegetables in the EU. Waste management, 77, 238-251.

Galintin, O., Rasit, N., \& Hamzah, S. (2020). Production and Characterization of Eco Enzyme Produced from Fruit and Vegetable Wastes and Its Influence on the Aquaculture Sludge. Biointerface Research in Applied Chemistry,11(3), 10205 - 10214

Ginting, N., Hasnudi, H., \& Yunilas, Y. (2021). Eco-enzyme Disinfection in Pig Housing as an Effort to Suppress Esherechia coli Population. Jurnal Sain Peternakan Indonesia, 16(3), 283-287.

Junaidi, R. J., Zaini, M., Ramadhan, R., Hasan, M., Ranti, B. Y. Z. B., Firmansyah, M. W., Umayasari, S, Sulistyo, A., Aprilia, R. D \& Hardiansyah, F. (2021). Pembuatan Eco-Enzyme sebagai Solusi Pengolahan Limbah Rumah Tangga. Jurnal Pembelajaran Pemberdayaan Masyarakat (JP2M), 2(2), 118-123.

Marleni, Y., Mersyah, R., \& Brata, B. (2012). Strategi Pengelolaan Sampah Rumah Tangga di Kelurahan Kota Medan Kecamatan Kota Manna Kabupaten Bengkulu Selatan. Naturalis: Jurnal Penelitian Pengelolaan Sumber Daya Alam dan Lingkungan, 1(1), 35-40.

Nazim, F., \& Meera, V. (2015). Use of garbage enzyme as a low cost alternative method for treatment of greywater. Indian Journal of Environmental Health 57(4):335-342

Nursalim, R., \& Sudibyo, P. I. (2020). Model 3R pada Pengelolaan Sampah di Lingkungan Universitas Bengkulu. Naturalis: Jurnal Penelitian Pengelolaan Sumber Daya Alam dan Lingkungan, 9(2), 159-169.

Ruyani, A., Parlindungan, D., Rozi, Z. F., Samitra, D., \& Karyadi, B. (2018). Implementation Effort of Informal Science Education in Bengkulu, Indonesia: A Small Learning Center for Life Sciences. International Journal of Environmental and Science Education, 13(9), 747-755

Wen, L. C., Ling, R. L. Z., \& Teo, S. S. (2021). Effective Microorganisms in Producing Eco-Enzyme from Food Waste for Wastewater Treatment. Applied Microbiology: Theory \& Technology, 28-36.

Yanti, D., \& Awalina, R. (2021). Sosialisasi dan Pelatihan Pengolahan Sampah Organik Menjadi Eco-Enzyme. Jurnal Warta Pengabdian Andalas, 28(2), 84-90. 
Zakianis, S., \& Djaja, I. M. (2017). The Importance of Waste Management Knowledge to Encourage Household Waste-Sorting Behaviour in Indonesia. International Journal of Waste Resources, 7(04).

Zulfikar, W., Widhiantari, I. A., Putra, G. M. D., Muttalib, S. A., Hidayat, A. F., \& Baskara, Z. W. (2021). Sosialisasi Zero Waste di Desa Kediri Kabupaten Lombok Barat. Jurnal Ilmiah Abdi Mas TPB Unram, 3(1). 